\title{
TOWARDS AN ACTIVE REUSE OF THE BUILT HERITAGE IN ROȘIA MONTANĂ - A STUDENT'S EXERCISE
}

\author{
Paul MUTICĂ \\ Technical University of Cluj-Napoca, Faculty of Architecture and Urban Planning, ROMANIA \\ paulmutică@yahoo.com, Paul.Mutica@arch.utcluj.ro \\ DOI: http://doi.org/10.23740/TID120174
}

\section{ABSTRACT}

Roșia Montană is currently a village (former town) in Transylvania, with a declining population of about 4,000. But it is at the same time one of the most famous villages in Romania, due to the controversy surrounding it, which led to major public manifestations and protests in the autumn of 2013. In a way, the project of Gabriel Resources, which sought to obliterate the historical site and replace it with an open pit gold mine and a cyanide lake was so outrageous that it actually helped popularize the vast heritage of the village and offered an incentive to promote it on the UNESCO World Heritage List, thus protecting it from further such claims.

The Faculty of Architecture in Cluj found this a great opportunity for an international workshop with our French colleagues in ENSA Clermont Ferrand, who were glad to travel to Cluj and exchange ideas and even a small project for a few days. During their stay, we visited the site and chose one of the most interesting but sadly deteriorated buildings as grounds for a restoration project - the Reformed Parsonage. Our workshop focused also on a documentary assignment that bid our students to search out for similar cases to Roșia Montană in Europe and the whole world, so as to draw some conclusions about what is specific and what is similar in this particular context.

This paper gives a glimpse into the research we undertook with our students and our findings. One such similar case we found with our students would be Kremnica in Slovakia, also sitting on a sizeable gold deposit coveted by a Canadian mining company that promoted open pit cyanide mining there. There are open pit mining sites that threaten to engulf entire towns like Cerro de Pasco (Peru), but also sites that have been put to better use like in Curitiba (Brazil) and Falun (Sweden) and have been converted in cultural venues. Overall, the goal of the effort was to use the entire collective to determine similar cases around the world, resulting in contextual and viable architectural projects, particularly adapted to the special situation in Roşia Montană, some of which will be presented in short as results of this research.

Keywords: Roșia Montană, architecture, community, heritage, development, gold-mining

\section{INTRODUCTION}

Roșia Montană is a realm of the extremes. For some it is the archetypal abandoned historical mining village with a rich past, but a derelict present and an even grimmer and uncertain future, while for others, more optimistic ones, it is a place of great potential, where the present shortcomings will eventually give way to better days, when people will gladly flock to see one of the most telling pieces of history this land has to offer. While a few opportunists see only the possibility of gold exploitation, for many of us it is more a symbol of civic freedom and maturity, one of the rare instances when "the street" challenged the corruption of the central establishment and, faced with a real and life-endangering threat, proved for the very first time that the popular voice and common sense actually have a say and could even win the day. 
However strangely, while some ponder the natural riches and others the heritage, environment or even the symbolic value of Roșia Montană, very few seem to pause and think about the local community, their drama among these political struggles, their prosperity or even survival. An indubitable truth remains though, without the revival of the sense of community that was badly damaged during this last decade here, a UNESCO heritage label will not suffice to guarantee the survival and continuous proper use of the built heritage of Roșia Montană.

There are many aspects to what Roșia Montană really is and it is very hard to pinpoint just one or another from the general context. Europa Nostra has campaigned for a long-term development plan for Roşia Montană for over a decade, which included the site being put in 2013 on its very first list of 7 Most Endangered heritage sites in Europe (europanostra.org). As usual, the risk of destruction came from human acts rather than from physical erosion. The town itself lies on top of Europe's largest gold deposit, coveted by a Canadian Gold Mining Corporation that launched an aggressive campaign of disinformation in order to achieve its goal: unlimited mining privileges, no matter the costs for the locals and for the environment. International organizations, such as ICOMOS, have repeatedly stated their concern about the danger that Roşia Montană is faced with if the mining project is being considered (ICOMOS, 2013).

Though first attested as a Roman settlement in 131 AD, The Auriferous Quadrilateral around Roșia Montană has been steadily mined for gold from prehistoric times and there is evidence of gold trade between the local people and the Mycenaean cultures, dating back to the $17^{\text {th }}$ century BC (Gündisch, 1998). After the Roman conquest of Dacia, it became the site of one of the most extensive Roman mining complexes in the world and, many centuries later, during the AustroHungarian period, it still provided the means of existence for a vibrant community of free miners, most of them having their own stamp mills (șteampuri), for a while, more than 400 of them. The artificially made lakes (called tăuri) that powered these stamp mills are among the only witnesses of this interesting period. Some hardworking miners have actually gone rich, a testament of which is the former Casino building in the historical centre. The village itself is $a$ traditional mining town frozen in time at an early moment of its urbanization (Bălteanu, 2013). This actually makes Roşia one of the longest-lived traditional mining centres known today (UNESCO Tentative List).

Yet, its downfall slowly started during the communist regime, when all mining activities were seized by the state operated Roşiamin Company. Open pit mining was favoured over underground digging and this meant the destruction of the Cârnic Mountain top coupled with first time use of cyanide leeching at Baia de Arieş. Open pit copper mining was also started at Roşia Poieni, where the artificial lake flooded the village of Geamăna, dislodging the inhabitants. Gold mining was however halted in 2003, after the Baia Mare cyanide incident which sent an alarm signal of what could happen here as well.

It was in the late 1990s that Roşia Montană Gold Corporation (RMGC) started promoting a project for the largest open pit mining in Europe here that was to completely churn up four mountains- over 220 million tons of rock and, alongside, the Roman galleries, 740 homes, several churches, and 9 cemeteries. Also the project meant the realization of a cyanide tailings lake of more than 100 hectares (according to some even more than 300 ha) that was a catastrophic threat to the environment (Haiduc, 2003; Academia Română, 2003; Vesalon \& Creţan, 2013). Yet, it took more than a decade for the society to react fully to this threat and, in 2013, just as a law project was introduced by the Romanian Government in order to authorize the project and bypass the environmental and heritage commissions' veto, more than 200,000 people started to protest in major cities both in Romania and the Diaspora. Thanks to this 
common effort that lasted for several months, the law project was finally aborted in Romanian Parliament and the RMGC project was halted indefinitely.

As the Government has changed so has the policy towards Roşia Montană and, on the $18^{\text {th }}$ of February 2016, the state finally managed to forward UNESCO the tentative list for Roşia Montană Mining Cultural landscape (UNESCO Tentative List), in an attempt to preserve it from RMGC.

While most scholarly articles about Roşia Montană focus either on the ecological or social aspects, it seems few focus on the endangered built heritage which, at least for architects, is just as valuable as the ailing local community. In fact, one cannot argue that there is little chance for the local community to survive unless the local built environment is maintained and reused. Forced resettlements into Recea or Roşia Montană Nouă are proof of this, as well as they were not successful in maintaining the community following relocation (Vesalon \& Creţan, 2012; Velicu, 2012).

\section{The issue of vernacular architecture as a palimpsest of local identity}

While the architecture of Roşia Montană displays obvious urban inspiration, it is clearly vernacular in nature, according to Bâlici (see Bălteanu, 2013). Lately, there have been numerous attempts of reinstating the unique value of vernacular architecture and a growing understanding of the dangers of inaction from the public authorities. Compared to other countries, Romania has had a less active role in preserving the vernacular heritage and the general public needs to be more informed on the subject in order to avert the irreversible destruction of this often disregarded treasure.

In this respect, Roşia Montană and its surroundings constitute a triad of valuable cultural, industrial, and natural landscape that have suffered a lot from inaction or deliberate destruction. It is not unfortunately a singular case. Nowadays, however, with the support of several NGO's, several public institutions have taken steps into educating the general public. For example, Roşia Montană is part of the ethnographic area of the Land of the Moți [Tara Moților], for which the Romanian Order of Architects (ROA) conducted a study and published a guide for arising consciousness among the local populace (Barbieri, 2012). Several other studies, conducted by either ROA, the Romanian Government or NGO's include, but are not limited to, A Building Guide for Maintaining the Local Identity (OART, 2008), A Building Guide for Piatra Craiului National Park (Munteanu, 2013) and Traditional Architecture (USR, 2015). Concern for preserving the aspect of the natural landscape existed as well, like the Management Plan for Munții Rodnei National Park (ROMSILVA, 2013).

Sustainable development goes hand in hand with vernacular architecture that has a minimal negative environmental impact and is generally best adapted to the local climate and landscape. Apart from being the background for habitation, architecture can provide a good incentive to build a sustainable economy based on agrotourism, on the revival of popular arts and crafts, and even on bio agriculture. Most noteworthy in this respect is the total conversion of Viscri (Braşov County), promoted by the Prince of Wales who bought a house there, from an abandoned Saxon village into a great tourist attraction that uses local identity as a main attraction (Iorio \& Corsale, 2014).

Finally, vernacular architecture around the world is a source for high tech innovation in building technology, including the use of wind traps for natural ventilation, green roofs and earthen walls, all employed in low carbon emission house designs.

It is in this context that our school (FAU UTC-N), namely the fourth year in architecture Synthesis by Design Studio, coordinated by assoc. prof. Ph.D. arch. Dorina Vlad and including prof. Ph.D. 
arch. M.I. Agachi, assoc. prof. Ph.D. arch. C. Purcar, lecturer Ph.D. arch. O. Olănescu, assistants S. Moldovan, R. Ciomagă, D. Stanca, N. Mirişan, M. Grama, eng. F. Matei and myself, with our 97 students, has organised an international workshop with our colleagues from École Nationale Supérieure d'Architecture de Clermont Ferrand(ENSACF), represented by enseign. Fabien Palisse, Patrick Leaud and Géraud Dodinet, along with 27 of their students, who travelled to Cluj on this occasion during February-March of 2016. Later on, during May, assoc. prof. Vlad and prof. Agachi travelled to ENSACF for the finalization of the workshop.

We also invited to Cluj assoc. prof. Ph.D. arch. Ştefan Bâlici from "Ion Mincu" University of Architecture and Urban Planning (UAUIM) Bucharest, one of the leading experts and organiser of several summer schools in Roşia Montană during the last years, who was kind enough to share his experiences in situ, including the Architecture Restoration Archaeology (ARA) Society' efforts to safeguard the built heritage of Roşia Montană such as the Adopt a House programme (see also http://www.adoptaocasa.ro).

This paper will briefly present a few of our findings, some of our students' projects, and the research we coordinated. It is important to underline that the article does not propose a theoretical and general approach and conceptualization, but focuses more on the practical aspects of architectural design, with direct implications for this particular context - Roşia Montană and its architectural heritage. As such, it falls under the category of applied research, rather than under those of basic or theoretical studies (see Roll-Hansen, 2009).

\section{AIMS \&METHODOLOGY}

Research in architecture can be divided into two main branches: direct observation research and indirect research. Whereas the first is concerned with analysing the physical conditions of either architectural objects or urban settings, as well as the current state of the community (employing the methods of social sciences for that purpose), the second takes from the already formed corpus of knowledge, whether it consists of archives, scientific articles and of literature, descriptions of similar case studies or even public documents (such as development strategies or design regulations and norms) and, sometimes, tends to be more general.

Naturally, along with our French colleagues, we assessed the importance of first hand observation of the architectural elements present and of mapping the landscape topography, but not prior to delving into the numerous writings and debates that centred on Roşia Montană (Figure 1). As such, the workshop was designed to encompass three relatively independent projects by our joined students, the first of which was tackled during the visit of the French team. Afterwards, the French colleagues returned to Clermont Ferrand, but we continued working separately on the remaining two projects for the reminder of the second semester. During our visit to Roşia Montană, we collaborated with our colleague eng. Sebastian Jucan, from the Cadastral Measurements Department of TUC-N, in order to draw the plan and coordinates of the historical centre, the setting for our student projects.

We identified three aspects of the valuable landscape in and around Roşia Montană, in accordance with the Cultural Heritage Management Plan of Opus (Opus, Atelier de Arhitectură, 2006, pp. 16-19), namely:

- traces of the industrial and mining landscape (remains of stamp mills, wagons, mine entries, etc.);

- traces of the altered natural landscape (including the artificial lakes, the roads and the open quarry at Cârnic); 
- the rural aspect of Roşia Montană itself, with consistent urban influences in architecture and settlement configuration around the main square.

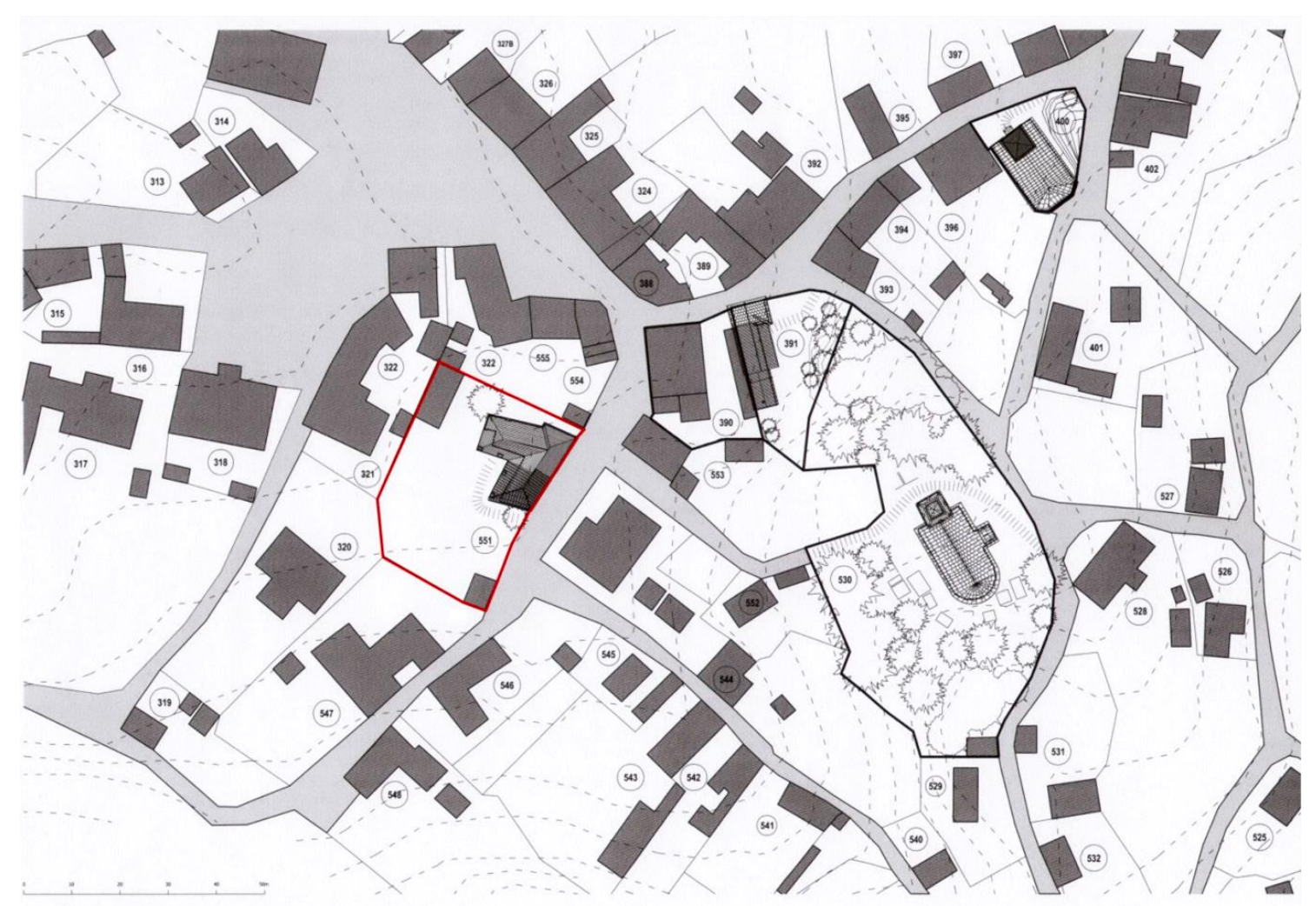

Figure 1: Central area of Roşia Montană. Red delimitation of the Reformed Parsonage

Source: Apostol \& Bâlici 2010, plate no. 7

The didactic goals of our three stage effort were:

- to familiarize our students with the complex context of Roşia Montană and its surroundings;

- to teach our students how to undertake a research assignment based on similar case studies around the world;

- to understand and even tackle some of the problems the local community was faced with through the proper design of a community centre.

In doing so, the purpose of this article is to share the following results:

- ways in which architectural interventions contributed to the welfare of communities in the aforementioned case studies;

- viable typologies of community centres as derived from the projects themselves, all having ample justification for their form, function and relations;

- viable attitudes towards the built heritage in Roşia Montană, namely towards the historical centre and particularly towards the Reformed Parsonage (Figures 2-7) (From 2002 until 2016, the Reformed parish dwindled, the ground floor was used as a pharmacy later and when the roof was damaged in time, no one restored it. The rain did the rest. Since it is private property no one does anything). 
As such, we considered the students' architectural projects as both original and creative, because they study the context and adopt a critical attitude towards it.

As mentioned before, there were three such assignments.

a. The first one required our students to design in just a few days a shelter for researchers and restorers - basically, a small housing unit that featured workspace for restorers and minimal comfort like toilets and showers. It was designed to be a mobile unit that could be relocated anywhere else so it was not connected to the local plumbing network and was intended to leave a minimum of traces after dismantlement.

Since it was a short assignment, designed to be solved in just a couple of days, intensive work, together with the French team and to be judged together also, it featured a minimum of documentation about Roşia Montană (especially since the unit could be then relocated anywhere else in the country according to the needs).

b. The second assignment was a documentation one about sustainable development in Mining Site Architecture, both in Romania and abroad, with the distinctive purpose of identifying as many interesting solutions for solving the problem of mono-functionality of these often abandoned mining sites. Aspects that needed the students' attention included cultural and historical context, social, political and economic aspects and, last but not least, architectural trends in similar case studies.

Since it was a documentation assignment, there was no project required of our students and it acted more as research for the third assignment-the community centre. Instead, students were required to write a short scientific article about their findings and to compile a PowerPoint presentation at the end.

The second assignment was now relevant as a fundament for this design endeavour, for unravelling all aspects connected to local architectural identity, as well as for finding similar examples around Romania and Europe. The preference for an urban aspect of wealthy residences in Roşia Montană is not uncommon but, as described above, not necessarily functional and, sometimes, a strange imitation with different building techniques or materials (the wooden pillars are plastered to give the illusion of more durable and expensive brick or stone ionic columns).

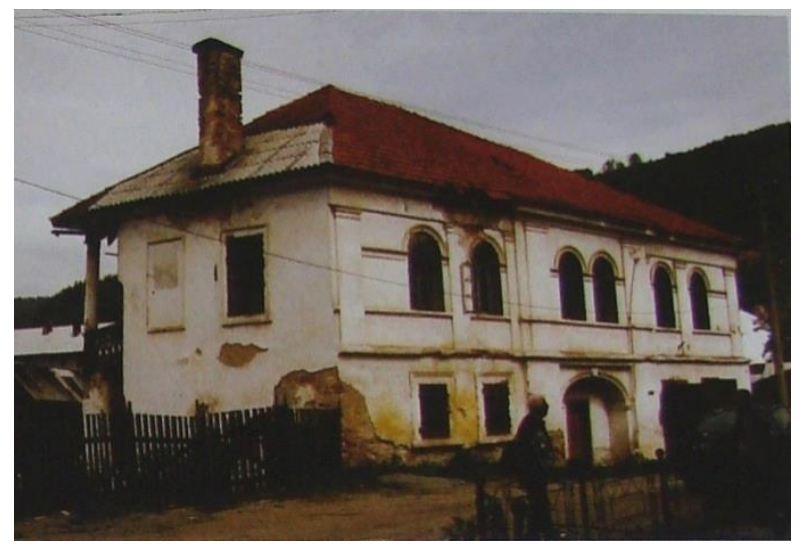

Figure 2: Reformed Parsonage ca. 2002 Source: Slotta \& Wollmann, 2002, p. 235

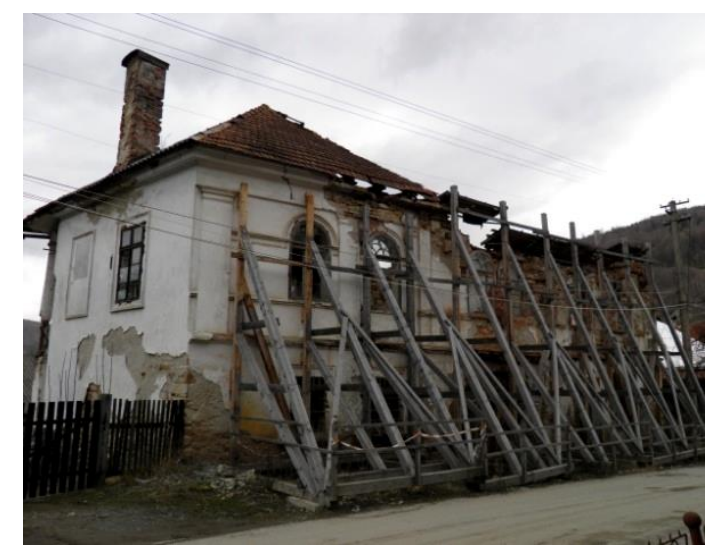

Figure 3: Reformed Parsonage in 2016 Photo: Paul Mutică, 2016 

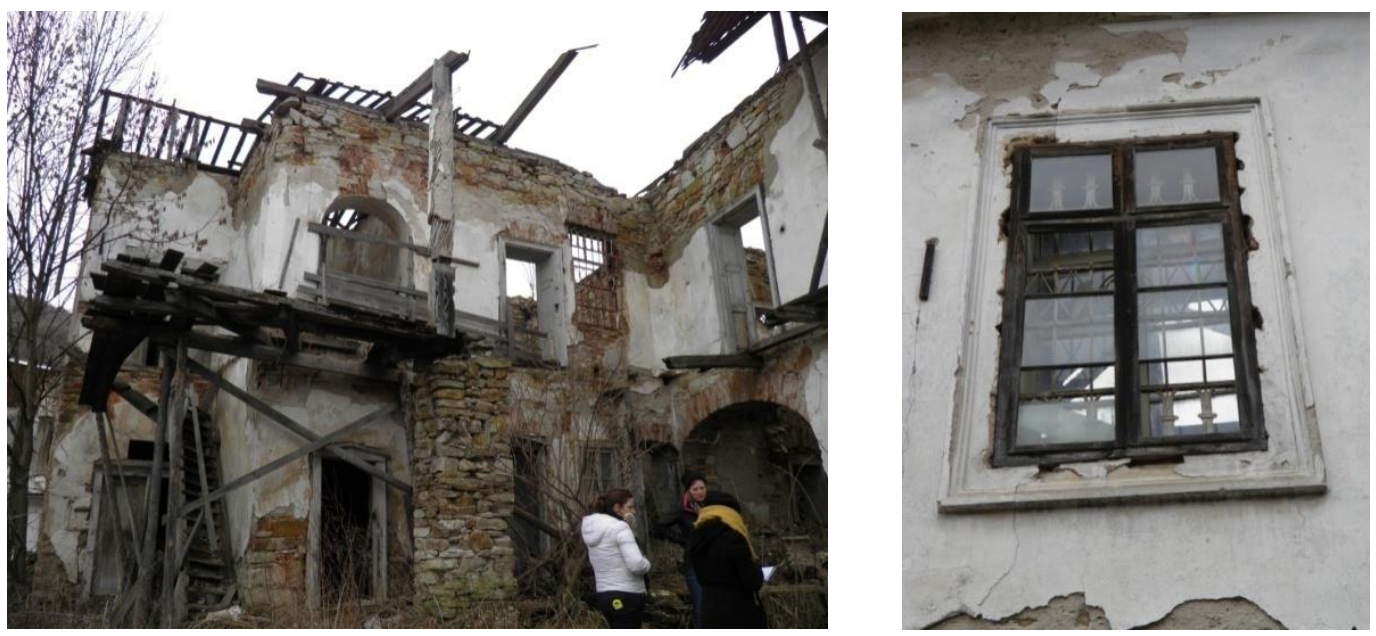

Figure 4: Reformed Parsonage courtyard view

Figure 5: Window detail

Photo: Paul Mutică, 2016
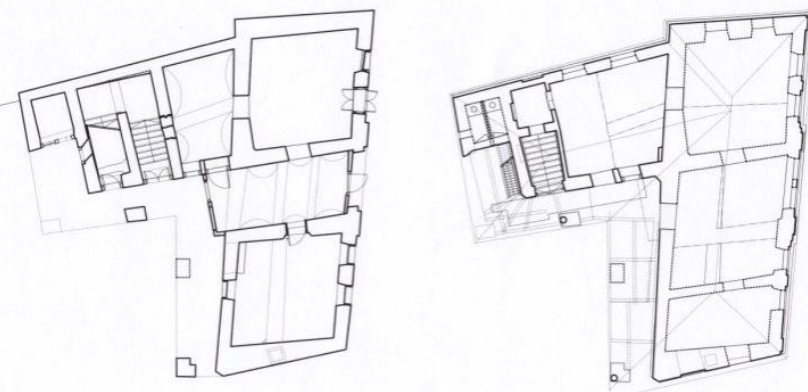

Photo: Paul Mutică, 2016

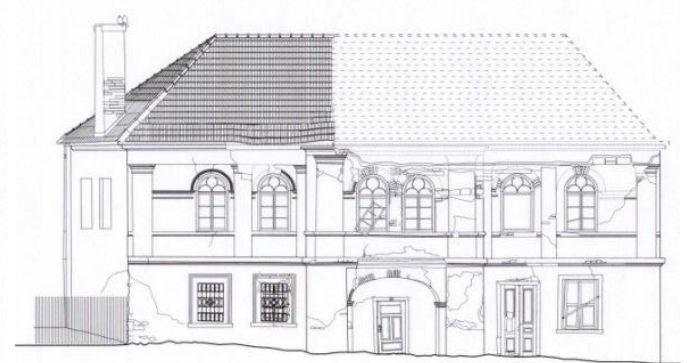

Figure 6: Reformed Parsonage plan views ground floor (left), first floor (right)

Figure 7: Main façade

Source: Apostol \& Bâlici, 2010, plate no. 42

Source: Apostol \& Bâlici, 2010, plate no. 41

c. The third and most extensive assignment was to design a Community Centre by converting and expanding the now abandoned Reformed Parsonage in Roşia Montană, as a conclusion to previous findings in their research. Though it is one of the oldest and most valuable buildings in the town, it fell into disuse and it is currently under serious threat of collapse due to natural erosion of the walls and roof. From the ARA description below, we notice the preference locals had for urban residences, despite living in a rural settlement:

The house was built in the middle of the $19^{\text {th }}$ century as a parsonage and dwelling, with commercial spaces on the ground floor, towards the street. In the post-war period it functioned as a pharmacy and pharmacist's service home. After 1990, the commercial space was also used as a general and grocery store. The building is the most complex and coherent example of classicism in Roşia Montană. The composition is symmetrical, with the marking of the central aisle as protruded from the plane of the façade, marked at ground level by a passageway to the backyard. Although the street does not present a continuous front and the access to the yard can be made by entering just near the house, the plan is organized according to this important element, the passageway, which is not, in this case, a 
functional necessity, but an architectural, aesthetic option. Besides, the passageway, lacking obvious functionality, was at one time obstructed by a wall in which a simple door opened. Behind this classicist façade, to the backyard, the upper floor is entered through a balcony aesthetically related to local architecture, accessible through a staircase embedded in the house's volume and covered with a vault. The wooden pillars of the balcony are plastered and made to imitate ionic style columns (Apostol \& Bâlici, 2010, p. 10).

Aspects of architectural restoration work and a contrast between the old and new intervention were to guide the students in their conceptual effort. Their project was to respect the authenticity of the existing building. The consolidation and restoration of the old parsonage was to identify and comply with the original structure and space (as mentioned in the Charters of Venice - 1964, Bura - 1979, Nara - 1994 and other international recommendations relevant -see Petzet, 2004 and Blandford, 2005).The specifics of Roşia Montană historical centre, namely a blend between rural and urban landscape as crystallized around the main square, were most important in this particular context also.

The Community Centre was to house several rooms, like a museum, media library, coffee shop, senior centre and an assembly room for local boy/girl scouts, plus the necessary administration and technical facilities. It was also meant to make the most of the extensive courtyard for outdoor gatherings when the weather allowed it, including community feasts and other social and cultural events.

\section{RESULTS AND DISCUSSION}

The resulting projects and their justifying principles will be analysed separately on this three assignment structure, each having its own findings and criteria for grading. As mentioned, the first assignment was given to both groups of students at the same time, during the visit of the French team in Cluj. They had just two days of work to finalize it and come up with a viable solution for a temporary accommodation unit. The second and third assignment developed for a longer period in the reminder of the second semester of 2016.

\section{First assignment: Temporary Accommodation for Restorers at Roşia Montană}

The commune of Roşia Montană has been in a steady population decline from the 1850s, when it had a maximum of 5,756 inhabitants (Varga, 2007). Nowadays, it has only 2,656 (according to the 2011 census), less than half of its population. As such, many houses have become derelict and others have even been demolished. Thus, the capacity for accommodating guests is rather limited, therefore the need for an independent dwelling and working shelter for researchers, very close to the archaeological grounds and the village centre. Since the shelter is bound to be temporary, it has to leave a minimum of traces on the land after its removal. Due to a minimal size restriction, many normal functions of the traditional house (like laundering for example) were to be externalized services acquired from or performed by the locals.

Our students studied the older traditional houses in Roșia Montană and found some characteristic features that some of them decided to implement. One such feature is the glass veranda that marks the entrance to many houses. Being in a mountainous region with colder air, the veranda is justifiable from a climatic point of view as an entrance buffer rather than an aesthetic preference 
on its own. Nevertheless, its practicality, flexibility and easiness to assemble were some of the secondary reasons why they actually chose to adopt it in their own interventions.
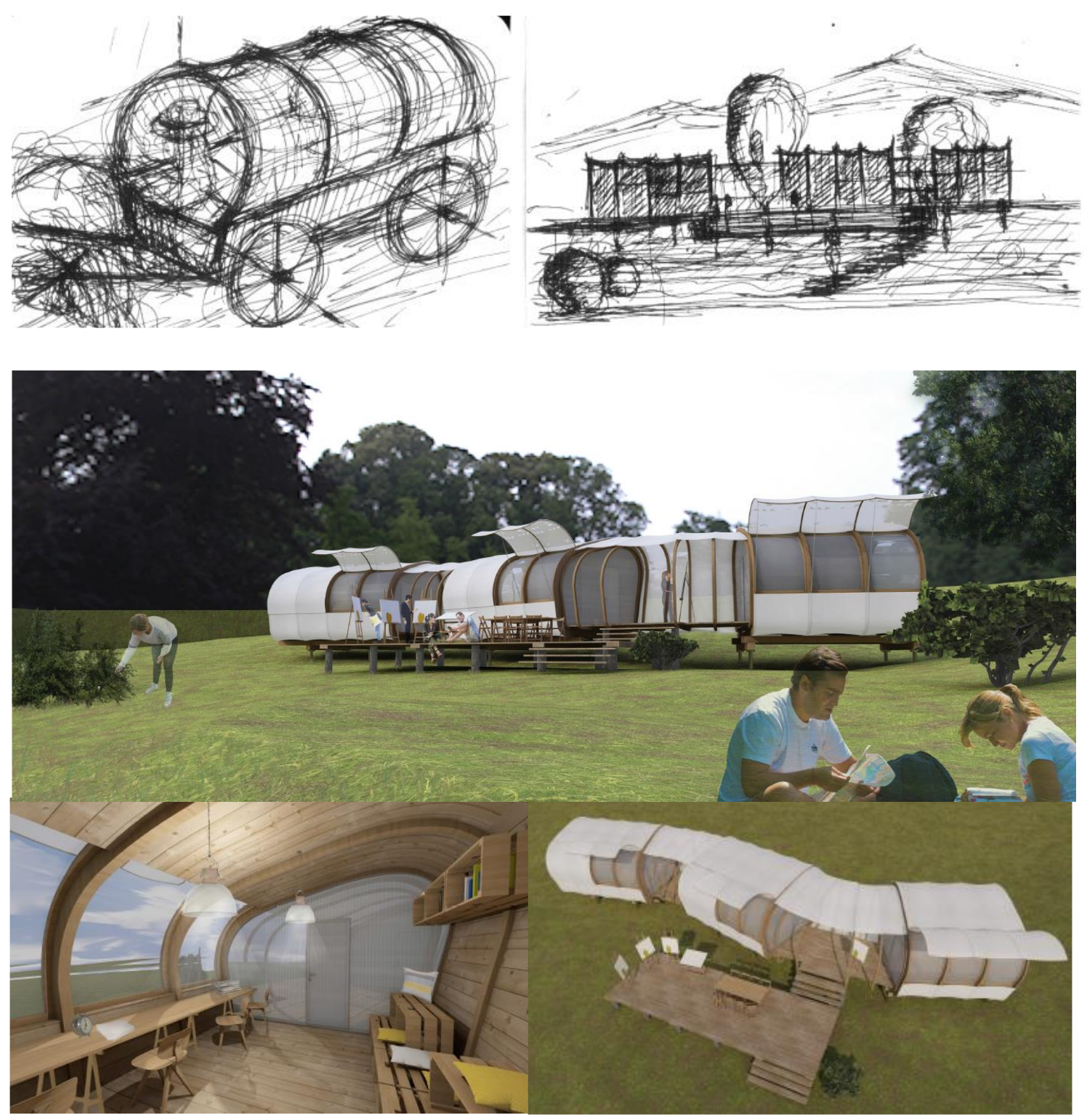

Figures 8-12: Project for Temporary Accommodation for Restorers at Roşia Montană

Source: students Oana Vaida \& Emilian Ciupercă, 2016

Whereas some chose to mimic the surrounding houses, others found more value in traditional wooden architecture in general or with respect to the wooden houses present in the Land of the Moţi [Jara Moţilor] in particular. While some were arguable as the specifics of the accommodation given in the assignment asked for a temporary shelter and the possibility of reuse in a different context, they were still interesting in terms of synthetic reinterpretations of folk architecture in a contemporary light. 
Another original approach was that of Oana Vaida and Emilian Ciupercă, who decided to make reference to the nomad character of the Moţi population that are living in and around Roşia Montană and, sometimes, travel in covered wagons to sell their artisanal woodwork in neighbouring towns. Their justification was that a temporary shelter was much smaller than a house and should blend in more than just one built context, therefore the contemporary reinterpretation of a covered wagon or caravan was more suited than a miniature house (see Figures 8-12).
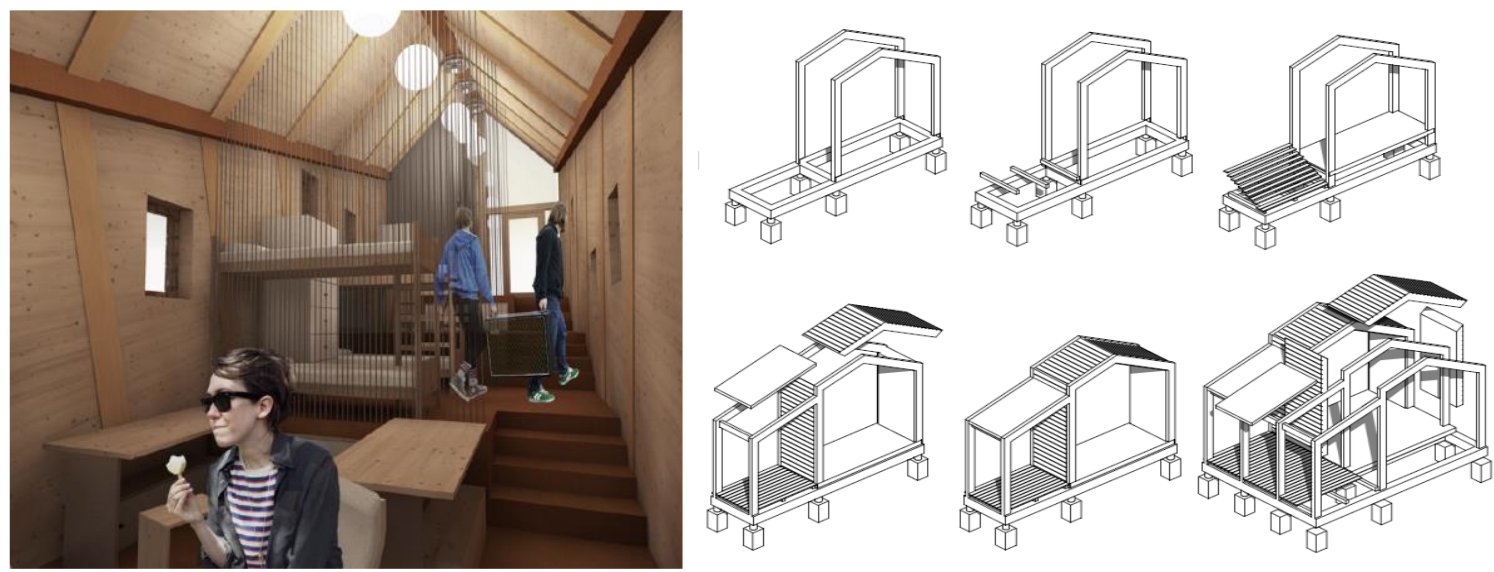

Figures 13, 14: Project for Temporary Accommodation for Restorers at Roşia Montană Source: students Anita Deak \& Alexandru Pomăzan, 2016 (left) and Adelina Ghineţ \& Vlad Dinoiu, 2016 (right)

These projects were appreciated also for answering technical criteria like modulation of the structure, ease of assembly and disassembly, functional flexibility and the use of natural, ecological materials, mainly but not limited to wood (Figures 13 and 14).

\section{Second assignment: sustainable development in the architecture of mining sites}

The second assignment delved into the context of Roşia Montană directly (analysing the vast amount of materials written in the last few decades about the historic, cultural, social, and economic situation), but also attempted a comparative view with similar cases of former mining settlements threatened with abandonment both in Romania and abroad.

Since this research was done by more than 40 teams of two students each, it meant that the results were both extensive and revealed some interesting facts. At the end of the assignment, all students presented their findings in a presentation to the workgroup (consisting of around eight student teams) and the best presentations were selected for view by everybody.

All endeavours started with the definition of cultural and industrial landscape. In order to provide a viable and sustainable development proposal, all strategies proved to put great emphasis on preserving and enriching the existent values of the site. For Roşia Montană, for example, the Cultural Tourism Centre organization identified a set of five main directions in their Alternative Strategy for Sustainable Development in Roşia Montană (Cultours, 2007, p. 3, p. 11):
a. ecological reconstruction of the mining affected areas,
b. rehabilitation of infrastructure and public services,
c. rehabilitation and preservation of cultural heritage,
d. development of a diverse, sustainable and competitive business environment,
e. development of social capital and community partnerships. 
But while these points were generalist and common goals for all similar case studies, the means to achieve them varied greatly. There were plenty of settlements with similar problems to Roşia Montană. Open pit mining for heavy metals is still common place, especially in developing countries. For instance, Cerro de Pasco silver mine in Peru slowly but continuously eats away at the fabric of the old town from the middle. Historical monuments are lost to cave-ins and the air is heavily polluted by lead and hazardous for the health (Dajer, 2015) (see Figures 17 and 18).

Kremnica (Figures 15 and 16), in Slovakia, also a historical mining town in a beautiful landscape and sitting on top of a large gold deposit, is threatened by a similar open pit mining and cyanide leaching lake project, promoted by Tournigan, a Canadian mining corporation. As the Slovaks were also reticent, a new approach by Šturecland Ortac attempts to convince the locals that an open pit mine could actually be an ecological improvement and shows the pit as a tourist attraction featuring guided tours, adventure sports, restaurants and even spas (brochure available at $h t t p: / / w w w . o r t a c s l o v a k i a . s k / p d f / s t u r e c \_b r o z u r a . p d f . p d f$, accessed March 2017).

The similarities between Kremnica and Roşia Montană are numerous. The corporations started to buy properties and promoted themselves as benefactors to the locals. Disinformation about a better tomorrow and employment opportunities hid the real goal of profit, no matter the cost and divided the community (Velicu, 2012, pp. 135-139). Instead of solving the issues of the mono-functional settlement, these projects only seemed to deepen that. Environmental hazards were often disregarded as well or deliberately hidden from public knowledge.

But there are also good examples that emerged in this research. Situations where the open pit mine had been closed, remained but a hole in the ground that was eventually turned into a different, more sustainable venue like a museum (Falun, Sweden), theatre (Dalhala, Sweden), opera (Opera de Arame, Curitiba, Brazil see Lerner, 2014, pp. 109-112) or even lake (Welzow, Germany) proved that with a minimum of effort yesterday's problems could turn into tomorrow's opportunities.

The most renown of these makeovers is Eden Project in Cornwall (Figures 19 and 20) that turned an abandoned clay pit into a world famous greenhouse with innumerable plant species from all over the world. Nicholas Grimshaw's project for the bio-domes was so innovative that it changed the way engineers build similar structures even today. By employing ETFE, a high grade inflatable polymer, instead of ordinary glass, Eden Project spans seven times longer, but with just $1 \%$ the total weight of a similar glass enclosed structure, meaning that the whole structure actually weighs less than the air it encloses (Pawlyn, 2010).

Some of the best examples we found employed great creativity in using the abandoned mine shafts for air tunnel experiments, edible fungus agriculture or even as wine cellars. But most importantly, the mining settlements themselves seem to have been reinvented. Whereas some traditional mining sites have become open air museums, listed with UNESCO, like Røros in Norway, a copper mining town frozen in its development in the $18^{\text {th }}$ century, Idrija in Slovenia, Europe's oldest mercury mine or Falun in Sweden, largest copper mine in Europe for centuries (see Falun Mine official site, http://www.falugruva.se/historia/historik-falu-gruva/1600-taletstorhetstiden/). Other, less prominent but better connected settlements used their location to gather tourists from large nearby urban centres. For example, Genk-C mine in Belgium was turned into a cultural venue with a theatre, cinema, restaurants, a public square and a design academy (http://www.visitgenk.be). Romania's Petrila case is somewhat similar with the conversion of older mining facilities into a community centre - the Centre Pompa-dou (former pump building renamed humorously to resound like Centre Pompidou in Paris), a studio theatre and more (see also Planeta Petrila, documentary directed by Andrei Dăscălescu). 


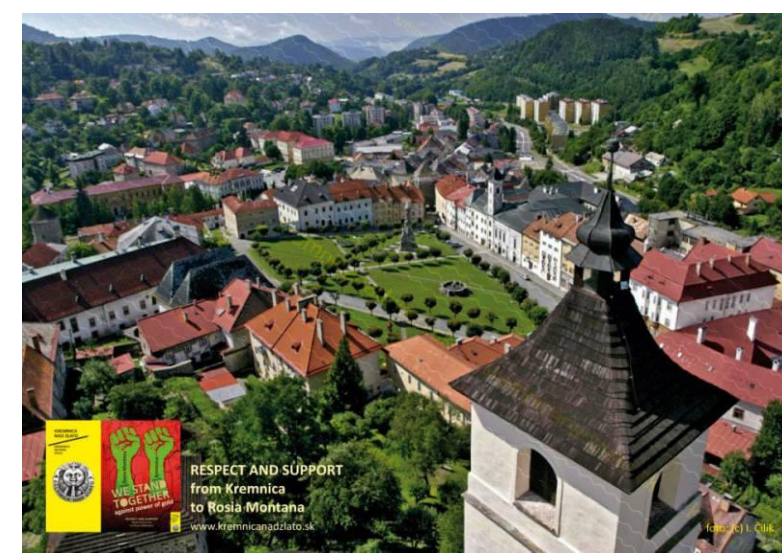

Figure 15: Kremnica, Slovakia, supports Roşia Montană during the protests in 2013

Source: kremnicanadzlato.sk

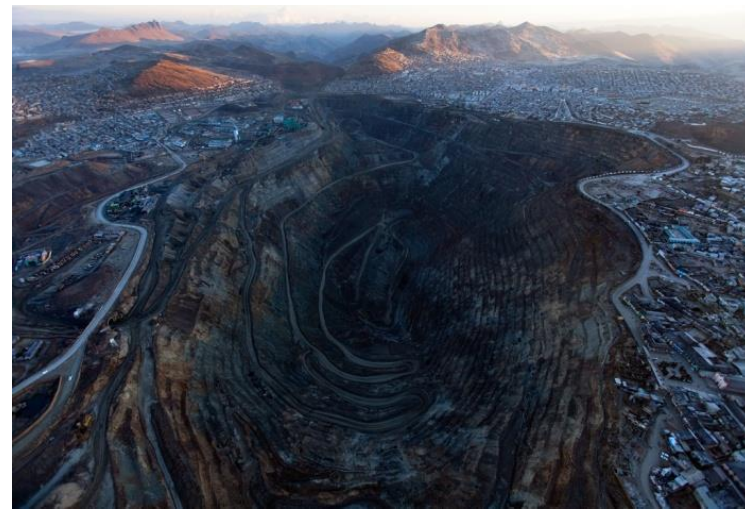

Figure 17: Cerro de Pasco, Peru, open pit silver mine

Source: Dajer, 2015
Miners' vision of prosperous Kremnica distressing for locals

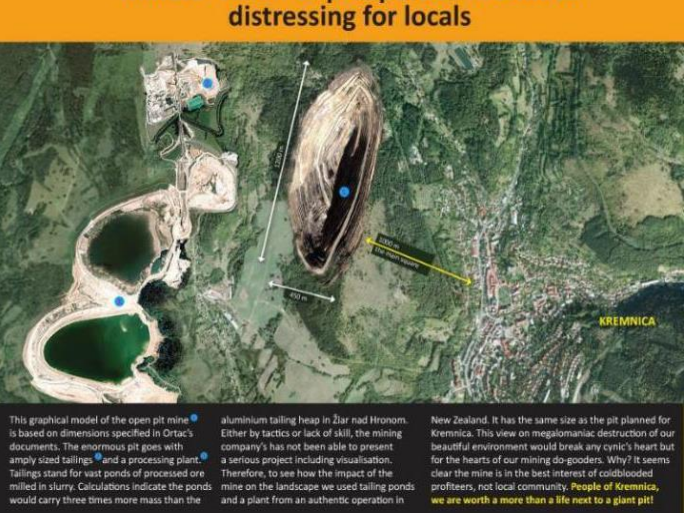

Figure 16: Open pit gold mining $1 \mathrm{~km}$

from Kremnica - simulation

Source: kremnicanadzlato.sk

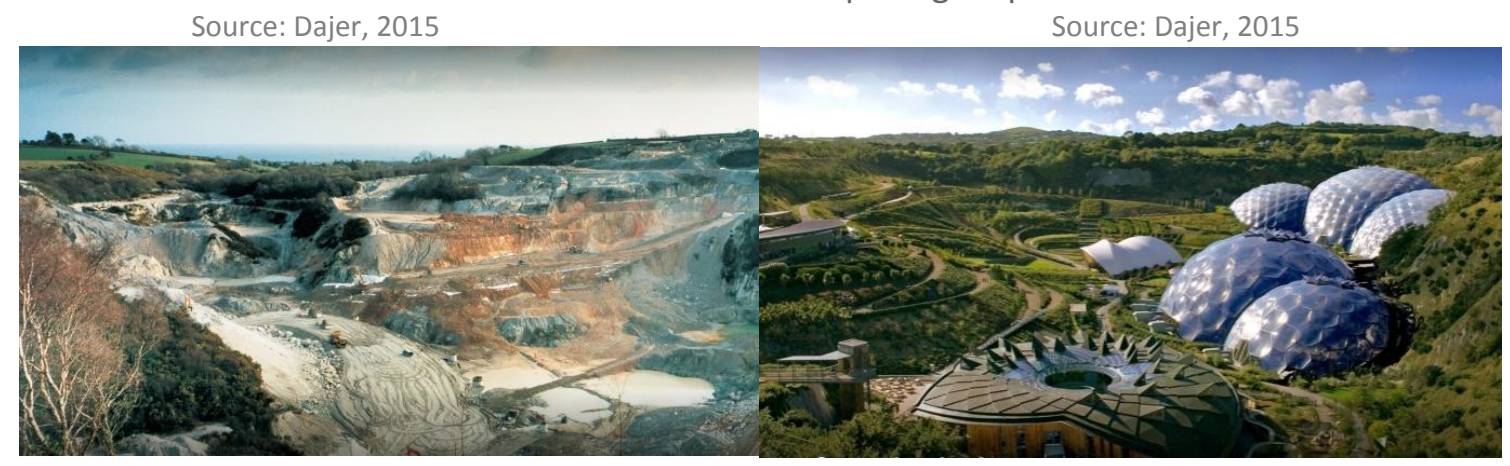

Figure 18: Street art, Cerro de Pasco, Peru, depicting air pollution

Figures 19, 20: Eden Project, Bodelva, Cornwall, UK, before: former clay pit; after: greenhouse garden and educational facility

Source: edenproject.com

While the invoked problem in Roşia Montană seems to be the notorious lack of funds and even of interest from the national authorities, it turns out many of these good examples were done with little capital investment, but (and this seems to be the underlying and deeper problem of Roşia Montană) with a great commitment from the community that decided it wants to help itself. Thus, the main setback in Roşia Montană actually seems to be the lack of a healthy communal sense and enthusiasm (as the community was targeted by RMGC in its efforts to evacuate the entire village), even though the potential for conversion into a tourist or cultural centre here exists in its fullest. 


\section{Third Assignment: Community Centre in the Former Reformed Parsonage of Roşia Montană}

It was from these premises that we undertook our third assignment, chosen deliberately on the site of the former Reformed Parsonage. While the building is almost completely ruined (see Figures 3-5), it is a beautiful example of $19^{\text {th }}$ century architecture and it has a rich history of being a public building as well.

The task of erecting a new building in the courtyard and making a connection between the old and new (both physically and aesthetically) was particularly demanding. Also, great attention was given to space as a catalyst for the ailing community of Roşia Montană that has been divided into two main belligerent groups for more than two decades (Velicu, 2012, pp. 129-135).

Our workgroup (guided by Mihai Grama and myself) adopted the attitude of balance between the old and new elements, namely between the restored former parsonage and the expansion that should adopt a contemporary, yet reverent form in order for this dialogue to work (Figures 21-26). Based on the attitude of rhyme, as described by Peter Smith, the expansion would have to present likeness tempered with difference (Smith, 2003, pp. 48-61). A simple copy, referred to by Smith as a submergent attitude, could easily fall into the trap of the pastiche. On the other hand, a completely indifferent contemporary building would create a fracture in the already fragile context of the historical centre in Roşia Montană.

The task was difficult and the students provided arguments for their respective solutions. While some opted for a daring approach, underlining the distance in time between the former and latter and the ensuing contrast in atmosphere as a positive aspect, Oana Vaida and Emilian Ciupercă chose to alter the genius loci as little as possible by burrowing their expansion almost entirely underground in order for it to be as little invasive as possible (see Figures 25 and 26). Between these two extreme attitudes, we had a full spectrum of projects, some with better arguments than others, but, overall, the experience was a success from both the students' point of view and ours.

Coming back to Vaida and Ciupercă's project, it was notable not only for its very low profile silhouette that meant the expansion would not be perceived as intruding on the original parsonage building, but, even more auspiciously, for the surprise the visitor would feel when entering the inner courtyard (Figure 26). There are actually two levels of courtyard, dynamically connected by a flight of stairs that double acts as an open air amphitheatre. The main pavilion has almost all emerging walls made of transparent glass, letting light in and offering a view towards the central piece - a furnace like vertical structure that acts as a pivot for the whole composition.

The project of Adelina Ghineț and Vlad Dinoiu (Figures 23 and 24) connects the old and new wings with a horizontal compositional element that marks the entrance in the courtyard and closes the street front at the same time, offering the image of a compact building at eye level. The courtyard declivity is terraced gently so as not to alter the perception of a single outdoor space. The succession of terraces well suited for accommodating different sorts of activities, including senior people playing board games or chess and, occasionally, large gatherings for festivals and ceremonies. The interior multifunctional hall is equally versatile, providing natural material finishings like wood and stone. The roof structure is also visible from the interior giving an impressive albeit warm atmosphere.

From the general plan disposition of Bernadett Kosa and Adelina Sav's project (Figure 22), we can very well see the old parsonage and new building across from each other, forming around a green interior courtyard, meant to be the main hub for all community activities. Exterior openness of space is mirrored on the inside of the expansion where the concrete pillar structure 
allows for multiple uses and flexibility. All compartments are temporary and can easily be reshaped. Adjacent to the green courtyard is a porch that connects it to the interior restaurant and meeting room and acts as an intermediary space, keeping excess sun and rainwater out and mimicking the old verandas found in various places around the historical Roşia Montană.
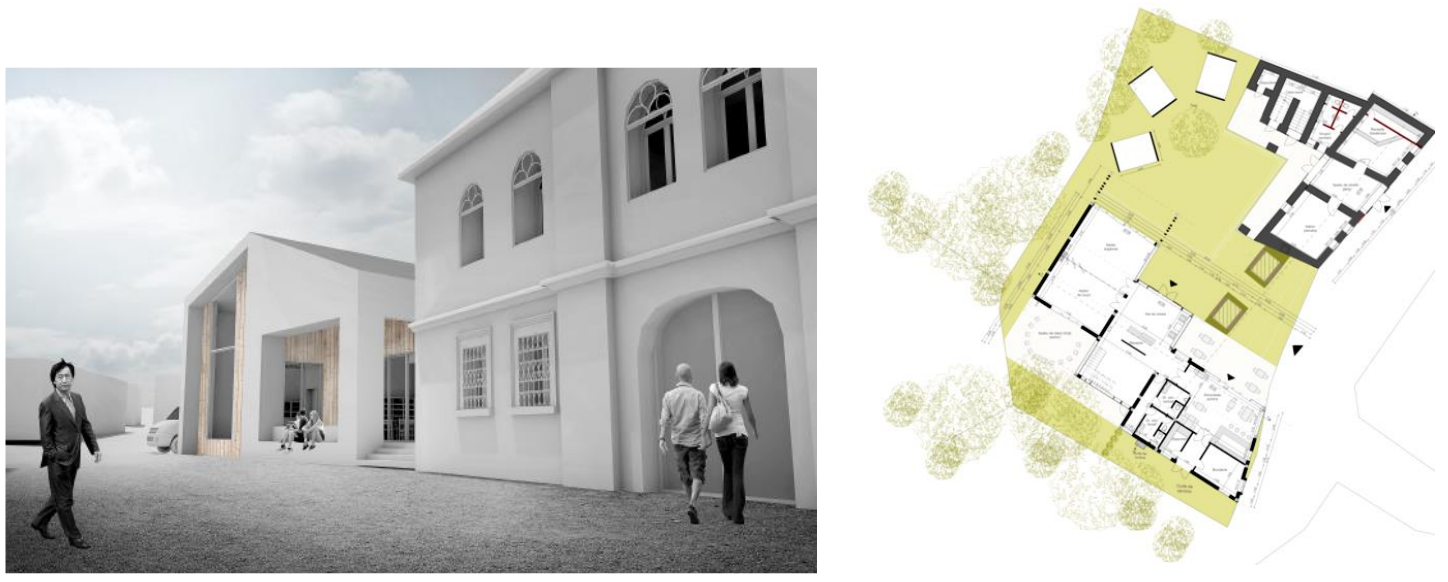

Figures 21, 22: Project for Roşia Montană Community Centre

Source: students Alexandru Nap \& Andrei Andone, 2016 (left) and Bernadett Kosa \& Adelina Sav, 2016 (right)
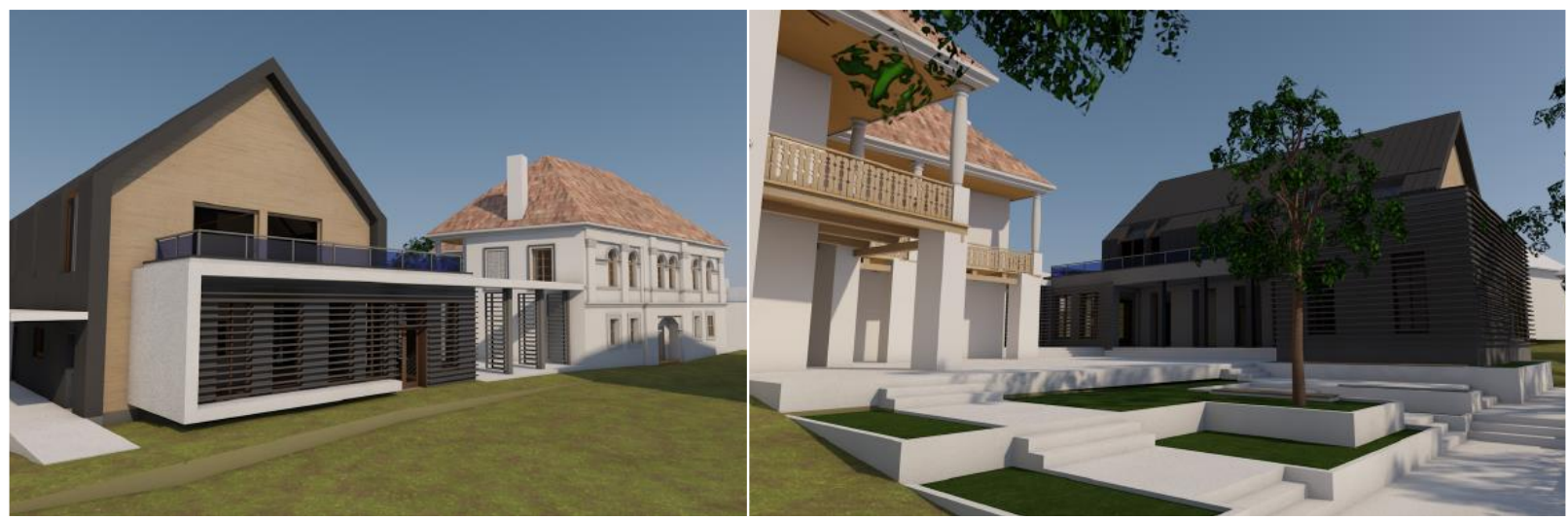

Figures 23, 24: Project for Roşia Montană Community Centre - front and backyard view Source: students Adelina Ghineț \& Vlad Dinoiu, 2016

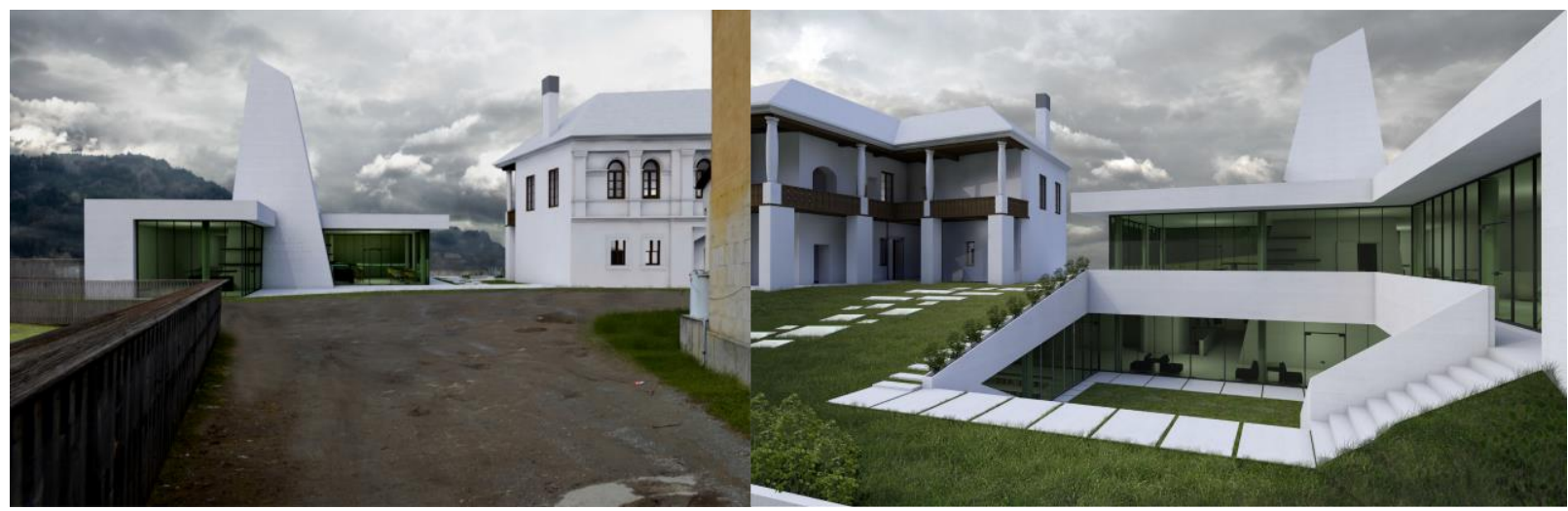

Figures 25, 26: Project for Roşia Montană Community Centre- front and backyard view Source: students Oana Vaida \& Emilian Ciupercă, 2016 
The challenge was also picked up by our French colleagues from Clermont Ferrand and it was interesting to see their outsiders', unaltered perspective of the heritage of Roşia Montană. Because they were not so familiar with the dispute surrounding the site and because Romanian vernacular architecture was new and exciting to them, the students from ENSACF actually approached the subject with great enthusiasm and creativity. Their interpretation of folk architecture ornaments, for example, proved a capacity for divergent thinking for some of them. For our own students it provided a different approach, and stirred their own creativity.

Last but not least, the students' research phase has actually yielded new results both for them and for us, providing a sustainable practice background based on good examples both at home and abroad.

\section{CONCLUSIONS}

The main goal of our endeavour was familiarizing our students with the issues of sustainable design in traditional architecture contexts. By choosing Roşia Montană, we presented them with a threefold provocation: integration within the complex natural, cultural and industrial landscapes as consecutive layers of the environment here. However, our findings during this process proved interesting enough by providing unexpected results in comparison with similar international situations which in turn prompted this paper for acknowledging them and making them public. Also the students had a fresh and creative perspective on the issue as proved by their final proposals for a community centre in Roșia Montană.

The three assignments obviously differ from each other in scope, methods and findings. They are however part of a singular effort to understand and present a physical object, well suited to the precise context of Roșia Montană. Aspects connected to the mining project and its effects are only mentioned to represent the many facets of the settlement, and to provide a general idea of the ailing community that needs help in surviving. The architecture alone (old or new) will not ensure its survival, but without preserving the old and good while designing the new, the community will most certainly be dissolved. The simple fact that they are students not architects yet does not take away from the originality of their work and ideas. Their findings can and sometimes prove to be advantageous to researchers that further develop on this theme.

While didactical in origin, this effort has a real practical outcome as the students are not simply taught information, but rather are encouraged to present their own findings and include them in their own proposal for a community centre that is both original and creative in the making.

This paper does not concern itself mainly with the didactical issues involved, but more with the actual projects that emerged, as well as with the findings derived from case studies both at home and abroad. In a way, the main topic would be the actual design process, comprising all stages, from gathering data to interpreting them from a critical point of view and, finally, creating an object to respond to these problems. The listed aspects focus on what has to be taken into account when solving this particular exercise: issues of context (physical, historical, social, architectural, etc.), of community and international practice, and they all weigh for the solutions our students provided and they are the findings and conclusion of this study in themselves. 


\section{ACKNOWLEDGEMENTS}

Many thanks go to the student teams we had the privilege to work with and for sharing with us their projects and their ideas that we helped come alive. Also I would like to thank the teaching staff for their input and contribution to this paper.

\section{REFERENCES}

ACADEMIA ROMÂNĂ (2003). Punctul de vedere al Academiei Române privind Proiectul de dezvoltare miniera Roşia Montană [Position of the Romanian Academy concerning the Mining Development Project for Roşia Montană]. Bucharest. Retrieved March 19 2017, from http://www.acad.ro/rosia_montana/pag_rm03_pv.htm

APOSTOL, V., \& BÂLICl, Şt. (eds.) (2010). Roșia Montană. Documente de arhitectură [Roșia Montană. Architectural Documents]. Bucharest: Editura Arhitectură. Restaurare. Arheologie.

ASOCIATIA ARHITECTURĂ. RESTAURARE. ARHEOLOGIE (2013). ICOMOS solicită imperativ statului român salvarea patrimoniului cu semnificație excepțională de la Roșia Montană și avertizează asupra pericolului iminent reprezentat de exploatarea minieră RMGC [ICOMOS Demands the Romanian State to Save the Exceptional Heritage of Roșia Montană and Cautions Against the Imminent Danger Represented by RMGC]. Retrieved March 19 2017, from http://simpara.ro/icomos-2013rezolutie-rosia-montana-565.htm

BĂLTEANU, A. (2013). Dosar patrimoniu Roşia Montană - interviu cu Ştefan Bâlici [Heritage File of Roşia Montană - Interview with Ştefan Bâlici]. Arhitectura, March. Retrieved March 19 2017, from http://arhitectura-1906.ro/2013/05/dosar-patrimoniu-rosia-montana-interviu-cu-stefan-balici/

BARBIERI, M. (coord.) (2012). Arhitectura locală, conștientizare și valorificare. Casa tradițională din Țara Moților - evoluție, specific, funcții contemporane [Local Architecture, Awareness and Improvement. The Traditional House in the Land of the Moți - Evolution, Characteristic Features, and Contemporary Functions]. Ordinul Arhitecților din România, filiala Alba.

BLANDFORD, C. (2005). Managing World Heritage Sites. Management Plans for UK World Heritage Sites. Conservation Bulletin, 50(Autumn). Retrieved March 19 2017, from https://content.historicengland.org.uk/images-books/publications/conservation-bulletin50/cb50pages1832.pdf/

CULTOURS - Centrul de Turism Cultural (2007). Strategie Alternativă pentru o Dezvoltare Durabilă în Roşia Montană [Alternative Strategy for a Sustainable Development in Roşia Montană]. Timişoara. Retrieved March 19 2017, from https://www.scribd.com/document/149371219/StrategieAlternativa-Rosia-Montana-CULTOURS

DAJER, T. (2015). High in the Andes, A Mine Eats a 400-Year-Old City. National Geographic, December. Retrieved March 19 2017, from http://news.nationalgeographic.com/2015/12/151202-Cerro-dePasco-Peru-Volcan-mine-eats-city-environment/

edenproject.com, last accessed on March 192017.

EUROPA NOSTRA. Europa Nostra supports nomination of Roșia Montană for UNESCO World Heritage Status. Retrieved March 19 2017, from http://www.europanostra.org/europa-nostra-supportsnomination-rosia-montana-unesco-world-heritage-status/

GÜNDISCH, K. (1998). Siebenbürgen und die Siebenbürger Sachsen. München: Langen-Müller.

HAIDUC, I. (2003). Proiectul Roşia Montană între riscuri şi beneficii. Academica, 13-14(April-May), 77-80.

IORIO, M., \& CORSALE, A. (2014). Community-Based Tourism and Networking: Viscri, Romania. Journal of Sustainable Tourism, 22(2), 234-255. 
kremnicanadzlato.sk, last accessed on March 192017.

LERNER, J. (2014). Urban Acupuncture. Washington DC: Island Press.

MUNTEANU, R. (2013). Ghid de construire în zona de dezvoltare durabilă a Parcului Național Piatra Craiului [Guide for Building in the Sustainable Development Area of the Piatra Craiului National Park]. Bucharest: Arhiterra.

OART (Ordinul Arhitecților din România filiala Transilvania) (2008). Ghid de construire pentru păstrarea specificului local, studiu de caz Platoul Ghețari, comuna Gîrda de Sus. Ghid destinat administrațiilor locale și întreprinzătorilor pentru construire în Parcul Natural Apuseni [Guide for Building While Preserving the Local Characteristic Features, Case Study Ghețari Plateau, Gîrda de Sus Commune. Guide for Local Administration and Entrepreneurs for Building in the Apuseni National Park]. AFCN și Consiliul Județean Alba.

OPUS, Atelier de Arhitectură. Centrul Istoric Roşia Montană. Plan de management al patrimoniului cultural [Historical Centre of Roşia Montană. Management Plan for the Cultural Heritage]. Retrieved March 19 2017, from http://www.simpara.ro/rm/plan_management.pdf

PAWLYN, M. (2010). Using Nature's Genius in Architecture. TED Conference. Retrieved March 19 2017, from https://www.ted.com/talks/michael_pawlyn_using_nature_s_genius_in_architecture

PETZET. M., \& ZIESEMER, J. (eds.) (2004). International Charters for Conservation and Restauration, ICOMOS. Retrieved March 19 2017, from http://www.icomos.org/en/what-we-do/disseminatingknowledge/publicationall/monographic-series/116-englishcategories/resources/publications/236-monumentsasites-i

ROLL-HANSEN, N. (2009). Why the Distinction between Basic (Theoretical) and Applied (Practical) Research Is Important in the Politics of Science. Centre for the Philosophy of Natural and Social Science Contingency and Dissent in Science Technical Report 04/09. London School of Economics and Political Science.

ROMSILVA (2013). Plan de management al Parcului Național Munții Rodnei [Management Plan for the Rodna Mountains National Park]. Retrieved March 19 2017, from http://www.parcrodna.ro/fisiere/pagini_fisiere/47/Plan\%20Management\%20PNMR\%20\%20201 3.pdf

SLOTTA, R., \& WOLLMANN, V. (2002). Roşia Montană als Bergort und seine Denkmäler. In: SLOTTA, R., WOLLMANN, V., \& DORDEA, I. (eds.), Silber und Salz in Siebenbürgen. Katalog zur Ausstellung im Deutschen Bergbau-Museum 4 (pp. 221-255). Bochum.

SMITH, P.F. (2003). Dynamics of Delight, Architecture and Aesthetics. London: Routledge.

UNESCO tentative lists (2016). Roșia Montană Mining Cultural Landscape. Retrieved March 19 2017, from http://whc.unesco.org/en/tentativelists/6082/

UNIUNEA ARHITECTILOR DIN ROMÂNIA (2015). Arhitectura Tradițională [Traditional Architecture], 2(35). Rețeaua Națională de Dezvoltare Rurală.

VARGA, A. Erdély etnikai és felekezeti statisztikája (1850-1992) [Ethnic and Religious Statistics of Transylvania]. Metrieved 19 March 2017, from http://varga.adatbank.transindex.ro/?pg=3\&action=etnik\&id=4700

VELICU, I. (2012). The Aesthetic Post-communist Subject and the Differed of Roşia Montană. Studies in Social Justice, 6(1), 125-141.

VESALON, L., \& CREȚAN, R. (2012). Development Induced Displacement in Romania: The Case of Roșia Montană Mining Project. Journal of Urban and Regional Analysis, 4(1), 63-75.

VESALON, L., \& CREȚAN, R. (2013). Mono-Industrialism and the Struggle for Alternative Development: The Case of the Roșia Montană Gold-Mining Project. Tijdschrift voor Economischeen Sociale Geografie, 104(5), 539-555. 